DOI:

\title{
PEMBERDAYAAN MASYARAKAT DUSUN KLAPALORO DAN TEMUIRENG DALAM PENINGKATAN KUALITAS KESEHATAN MASYARAKAT
}

\author{
Ambar Pratiwi ${ }^{1}$, Septiyan Haryanto ${ }^{2}$, Johan Setiawan ${ }^{3}$, Satrio Cahyo Wibowo ${ }^{4}$ \\ Universitas Ahmad Dahlan Yogyakarta ${ }^{1,2,3,4}$ \\ Email: ambar@bio.uad.ac.id ${ }^{1}$
}

\begin{abstract}
ABSTRAK
Peningkatan kualitas kesehatan masyarakat dari segi kesehatan fisik dan lingkungan dapat ditingkatkan dengan berbagai upaya, diantaranya adalah pengenalan perilaku hidup sehat seperti membiasakan gosok gigi, pengukuran indeks masa tubuh, pengelolaan sampah, serta peningkatan nilai gizi komsumsi masyarakat. Kegiatan pengabdian ini bertujuan untuk melakukan pendampingan dalam pemberdayaan masyarakat di dusun Klapaloro dan Temu Ireng dalam pengelolaan sampah rumah tangga dan pemanfaatan produk local untuk meningkatkan nilai gizi konsumsi masyarakat. Sehingga dengan adanya kegiatan ini diharapkan dapat terjadi peningkatan perilaku hidup sehat pada masyarakat dusun Klapaloro dan Temu ireng. Metode pelaksanaan pengabdian ini adalah dengan penyuluhan, pendampingan dan praktek. masyarakat di dusun Klapaloro dan Temu ireng telah mengalami peningkatan kesadaran dalam pengelolaan sampah rumah tangga, karena dalam pengelolaan limbah rumah tangga telah melakukan pemisahan limbah organik dan yang non arganik. Warga dusun telah mengalami peningkatan perilaku hidup sehat dengan selalu menjaga kebersihan diri dan meningkatkan gizi konsumsi buah dan sayur setiap harinya. Peningkatan ini diharapkan dapat selalu dipertahankan dan ditingkatkan sehingga tercipta masyarakat yang sehat baik fisik maupun lingkungannya.
\end{abstract}

Kata kunci : pemberdayaan, kesehatan masyarakat, Klapaloro dan Temu Ireng.

\begin{abstract}
Improving the quality of public health in terms of physical and environmental health can be improved by various efforts, including the introduction of healthy living behaviors such as getting used to brushing teeth, measuring body mass index, waste management, and increasing the nutritional value of community consumption. This service activity aims to provide assistance in community empowerment in Klapaloro and Temu Ireng in managing household waste and the use of local products to improve the nutritional value of community consumption. So that with this activity it is expected that there will be an increase in healthy life behavior in the community of Klapaloro and Temu ireng. The method of implementing this service is by counseling, mentoring and practice. the community in Klapaloro and Temu ireng have experienced increased awareness in managing household waste, because in the management of household waste the separation of organic and non-organic waste has been carried out. Hamlet residents have experienced an increase in healthy living behavior by always maintaining personal hygiene and increasing nutrition of fruit and vegetable consumption every day. This increase is expected to always be maintained and improved so as to create a society that is healthy both physically and environmentally.
\end{abstract}

Keywords : empowerment, public health, Klapaloro and Temu ireng 


\section{PENDAHULUAN}

Kesehatan masyarakat merupakan kondisi masyarakat yang stabil, yang sehat baik fisik maupun psikologis (Elliana dan Sumiati, 2016). Kondisi masyarakat yang sehat tidak hanya bisa diukur dari tingkat kesehatan fisik dan psikologis, tetapi juga didukung oleh kesehatan lingkungan. Kesehatan lingkungan sangat penting untuk mendukung peningkatan kualitas kesehatan masyarakat. Lingkungan merupakan segala sesuatu yang ada disekitar manusia yang dapat menentukan keberlangsungan hidup manusia. Kualitas lingkungan juga akan berpengaruh terhadap kualitas kesehatan manusia. Lingkungan di sekitar dusun Klapaloro dan Temu ireng merupakan bukit dengan banyak ditumbuhi banyak pohon. Pohon yang tumbuh merupakan pohon naungan dan budidaya. Jenis tanaman yang dibudidayakan antara lain padi, jagung, singkong, ubi, kacang tanah, cabai.

Peningkatan kualitas kesehatan masyarakat dari segi kesehatan fisik dan lingkungan dapat ditingkatkan dengan berbagai upaya, diantaranya adalah pengenalan perilaku hidup sehat seperti membiasakan gosok gigi, pengukuran indeks masa tubuh, pengelolaan sampah, serta peningkatan nilai gizi komsumsi masyarakat. Perbaikan nutrisi dan kesehatan pada anak dan remaja dapat diketahui dari perhitungan nilai IMT (Indeks Massa Tubuh). IMT adalah hasil perhitungan dari perbandingan BB (Berat Badan) dan TB (Tinggi Badan) melalui rumus BB/TB2 (kg/m2) (Putra et al., 2016). Sistem pengumpulan sampah yang dilakukan oleh masyarakat belum baik. Hal tersebut dapat dilihat dari sampah yang di buang oleh masyarakat kawasan tersebut, untuk membuangnya tidak memisahkan antara sampah organik dan non organik. Hal ini dapat terciptanya lingkungan yang bersih, sehingga dapat berpengaruh terhadap kesehatan masyarakat dan lingkungan (Sahil et al., 2016).

Kekayaan bahan local dari Klapaloro dan Temu ireng berupa singkong. Singkong mengandung amilum, yang merupakan karbohidrat yang dapat dimanfaatkan sebagai sumber bahan pangan. Salah satu alternatif pengolahan singkong adalah dengan dimodifikasi menjadi tepung. Modified Cassava Flour (tepung ubi kayu yang dimodifikasi), yakni tepung dari ubi kayu yang diproses menggunakan prinsip memodifikasi sel ubi kayu salah satunya dengan cara fermentasi. Mikrobia yang mendominasi selama proses fermentasi tepung ubi kayu ini adalah bakteri asam laktat. Mikroba tumbuh menghasilkan enzim pektinolitik dan sellulolitik yang dapat menghancurkan dinding sel ubi kayu sehingga terjadi penguraian granula pati. Keunggulan MOCAF antara lain yaitu, mempunyai kandungan serat terlarut lebih tinggi dibanding dengan tepung singkong, mempunyai kandungan kalsium lebih tinggi (58\%) dibanding padi $(6 \%)$, dan gandum (16\%), mempunyai daya kembang yang setara dengan 
tepung gandum, serta mempunyai daya cerna yang tinggi dibandingkan dengan tapioka (Putri and Kurnia, 2017).

Berdasarkan permasalahan yang ada di masyarakat terkait dengan pengelolaan sam[pah yang belum baik dan upaya peningkatan nilai gizi konsumsi dengan memanfaatkan produk lokal, tujuan dari kegiatan pengabdian ini adalah untuk melakukan pendampingan dalam pemberdayaan masyarakat di dusun Klapaloro dan Temu Ireng dalam pengelolaan sampah rumah tangga dan pemanfaatan produk local untuk meningkatkan nilai gizi konsumsi masyarakat. Sehingga dengan adanya kegiatan ini diharapkan dapat terjadi peningkatan perilaku hidup sehat pada masyarakat dusun Klapaloro dan Temu ireng.

\section{METODE}

\section{Alat dan Bahan}

Alat-alat yang digunakan dalam kegiatan ini adalah timbangan, meteran, sikat gigi, piranti memasak. Bahan-bahan yang digunakan dalam kegiatan ini adalah tepung mokaf, odol dan sampah rumah tangga.

\section{Jalannya Pengabdian}

\section{Penyuluhan}

Penyuluhan mengenai peningkatan perilaku hidup sehat dilaksanakan pada tanggal 1,2 dan 5 Februari 2018 (@50 menit), target peserta para ibu, bapak-bapak dan anak-anak. Materi yang disampaikan adalah memberi penyuluhan tentang pentingnya ASI ekslusif, pelatihan JUMANTIK (juru pemantau jentik) dan penyuluhan pentingnya konsumsi buah dan sayur secara teratur.

\section{Praktek}

Kegiatan praktek yang dilakukan antara lain adalah:

1. Kegiatan pengelolaan sampah berupa memberi pengetahuan tentang manajemen sampah, pengolahan sampah. Program ini di lakukan pada tanggal 3, 27, 30 Januari 2018 dan 5, 21 Februari 2018 (@150 menit).Target Peserta seluruh warga.

2. Pengukuran IMT dan Praktek Cuci tangan dan Gosok Gigi yang benar. Kegiatan ini dilaksanakan pada tanggal 25 Januari, 04, 07, 18 Februari 2018 (@100 menit). Target peserta anak-anak SD.

3. Pelatihan tata boga diantaranya pelatihan mengolah singkong menjadi bola-bola ubi, membuat nugget tempe, dan membuat tepung mocaf, membuat olahan tepung mocaf 
menjadi brownies. Kegiatan ini dilaksanakan pada 1,2,3,5,6,7,8,9,12,16,19 Februari 2018 (@100 menit). Kegiatan ini ditujukan untuk remaja dan ibu-ibu.

\section{HASIL, PEMBAHASAN, DAN DAMPAK}

Pelaksanaan kegiatan promosi kesehatan rumah tangga dan keluarga merupakan salah satu kegiatan promotif guna meningkatkan pengetahuan masyarakat dalam mengelola dan mengoptimalkan derajat kesehatan. Kegiatan ini memiliki tujuan untuk mendukung upaya pemberdayaan masyarakat terutama ibu untuk tahu, mau dan mampu berperilaku hidup bersih dan sehat dalam lingkup rumah tangga. Sasaran dari kegiatan ini adalah ibu-ibu Dusun Klapaloro dan Temu Ireng, karena ibu memiliki peran penting dalam melindungi, meningkatkan dan mengoptimalkan kesehatan keluarga. Salah satu kegiatan yang dilakukan untuk meningkatkan kesehatan keluarga adalah penyuluhan Perilaku Hidup Bersih Sehat (PHBS). Pada kegiatan ini sasaran pesertanya dalah ibu-ibu, bapak-bapak dan anak-anak. Kegiatan yang dilaksanakan yaitu memberi penyuluhan tentang pentingnya ASI ekslusif, pelatihan JUMANTIK (juru pemantau jentik) dan penyuluhan pentingnya konsumsi buah dan sayur secara teratur. Pelatihan PHBS bertujuan untuk meningkatkan derajat kesehatan masyarakat.

Limbah merupakan barang-barang bekas yang nantinya akan dibuang ke tempat sampah. Masyarakat beranggapan bahwa sampah itu tidak akan berguna lagi, maka dari itu sampah itu akan dibuang atau bahkan dibakar yang menyebabkan polusi udara. Oleh karena itu perlu dilakukan pendampingan dan praktek pengelolaan sampah. Kegiatan yang dilakukan adalah pengadaan tempat sampah, pemisahan sampah serta pengolahan sampah. Kegiatan pengenalan sampah berupa memberi pengetahuan tentang jenis-jenis sampah dan manajemen sampah yang bertujuan untuk mengetahui perbedaan sampah organik dan anorganik.

Pengadaan tempat sampah dilakukan dengan membuat tempat sampah sesuai dengan jenisnya yaitu membedakan tempat sampah organik dan anorganik. Penempatan tempat sampah berada di 4 sudut yaitu Masjid, Balai Dusun, Gardu RT 01 dan Gardu RT 02. Kegiatan pengadaan tempat sampah bertujuan agar masyarakat dapat memilah ketika membuang sampah. Pelatihan pemanfaatan limbah ini diharapkan mampu memanfaatkan barang-barang bekas menjadi kerajinan yang unik dan mempunyai nilai jual tinggi. Dalam hal ini tentu akan meningkatkan perekonomian masyarakat setempat. Selain itu juga akan mengasah kreatifitas bagi anak-anak dan remaja dalam membuat kerajinan dari barangbarang bekas. Adapun pelatihan pemanfaatan limbah ini antara lain: membuat tempat pensil 
dari botol-botol bekas, membuat tirai dari cup minuman bekas, dan penyuluhan tentang pentingnya cinta lingkungan untuk anak-anak. Sasaran dari kegiatan pelatihan sampah plastik yaitu ibu ibu kegiatan ini berlangsung dengan melakukan pelatihan dan praktek langsung dengan menggunakan bahan disekitar yang sudah tidak terpakai lagi. Pelatihan sampah plastik ini menggunakan kantong plastik (kresek) yang sebelumnya sudah di setrika dengan dilapisi kertas minyak kemudian dapat dijadikan sebagai vas bunga dan hiasan yang lainnya. tujuan dari kegiatan ini adalah memanfaatkan sampah yang sudah tidak terpakai lagi dan meminimalisir pembakaran sampah plastik dan meningkatkan pendapatan ibu-ibu dari hasil pembuatan kerajinan tangan dari plastik bekas.

Pengolahan sampah dapat juga menghasilkan pupuk yang dapat mendorong intensifikasi program pertanian dan perkebunan. Tujuan dari program ini untuk memberi alasan kepada para petani terkait pupuk padat dan pupuk cair organik yang dapat digunakan untuk pertanian atau perkebulan serta sebagai upaya memperkenalkan pertanian yang ramah lingkungan dengan menggunakan pupuk organik dengan bahan-bahan yang mudah didapat.

Program berikutnya adalah pendanpingan dan praktek PHBS merupakan upaya untuk memberikan pengalaman belajar atau menciptakan suatu kondisi bagi individu, keluarga, kelompok dan masyarakat dengan membuka jalur komunikasi, memberikan informasi dan edukasi untuk meningkatkan pengetahuan, kepedulian, sikap dan perilaku sehat masyarakat, sehingga membantu masyarakat untuk mengatasi masalah kesehatannya sendiri dan dapat menerapkan cara-cara hidup sehat dalam rangka menjaga, memelihara dan meningkatkan derajat kesehatan. Sasaran PHBS ini adalah anak-anak, sasaran ditujukan pada anak-anak karenabiasanya anak-anak kurang memperhatikan perilaku-perilaku mereka tentang kesehatan. Kegiatan program kerja ini dilaksanakan di masjid Ainun Jariyah, karena di masjid terdapat keran air yang biasanya digunakan sebagai tempat wudhu. Kegiatan PHBS yang dilakukan adalah pelatihan gosok gigi yang baik dan benar. Selain itu dilakukan pendampingan dan praktek cara cuci tangan yang ditujukan kepada anak-anak TK dan TPA. Kegiatan ini memberi pengetahuan tentang bagaimana cara mencuci tangan dengan baik, untuk menjaga kebersihan tangan dan pola hidup bersih dan sehat. Kegiatan ini berjalan lancar.

Program pengukuran Indeks Masa Tubuh (IMT) memberikan informasi mengenai berat badan ideal dan sehat untuk tubuh manusia berdasarkan berat dan tinggi badan dengan metode IMT (Indeks Masa Tubuh)/BMI (Body Massa Indeks). Tujuan dari program ini untuk menunjukkan kategori berat badan seseorang apakah sudah proporsional atau belum. Sasaran 
dari kegiatan ini adalah anak-anak kelas 1-6 SD. Materi yang diberikan pada kegiatan ini adalah informasi mengenai IMT, cara menghitung IMT dan kriteria IMT yang normal serta diakhiri dengan pengukuran berat badan dan tinggi badan.

Pelatihan pembuatan tepung mocaf yang dilakukan bermaksud untuk memberi pengetahuan kepada masyarakat tentang pembuatan tepung mocaf, sehingga dapat dimanfaatkan untuk membuat berbagai olahan makanan, selain itu dapat meningkatkan perekonomian warga yang di dapat dari hasil pertanian. Program pelatihan pembuatan tepung mocaf sasarannya yaitu ibu-ibu. Pelatihan tata boga diantaranya pelatihan mengolah singkong menjadi bola-bola ubi, membuat nugget tempe, dan membuat olahan tepung mocaf menjadi brownies. Kegiatan ini ditujukan untuk remaja dan ibu-ibu. Kegiatan ini bertujuan untuk memberi wawasan baru tentang dunia kuliner. Kegiatan ini berjalan lancar dan antusiasme remaja perempuan dan ibu-ibu sangat tinggi.

Pada pelaksanaan pengabdian ternyata tidak sebaik yang direncanakan, karena dalam pelaksanaannya terdapat beberapa hambatan. Hambatan-hambatan tersebut antara lain kurangnya kemampuan masyarakat dalam meningkatkan potensi produk lokal olahan makanan yang lebih bergizi dan bernilai ekonomi yang tinggi. Tetapi hambatan ini menjadi peluang bagi kegiatan selanjutnya dalam diversifikasi olahan pangan lokal.

\section{SIMPULAN}

Berdasarkan hasil kegiatan pengabdian dapat disimpulkan bahwa masyarakat di dusun Klapaloro dan Temu ireng telah mengalami peningkatan kesadaran dalam pengelolaan sampah rumah tangga, karena dalam pengelolaan limbah rumah tangga telah melakukan pemisahan limbah organik dan yang non arganik. Warga dusun telah mengalami peningkatan perilaku hidup sehat dengan selalu menjaga kebersihan diri dan meningkatkan gizi konsumsi buah dan sayur setiap harinya. Peningkatan ini diharapkan dapat selalu dipertahankan dan ditingkatkan sehingga tercipta masyarakat yang sehat baik fisik maupun lingkungannnya.

\section{DAFTAR PUSTAKA}

Eliana, S. Sumiati. 2016. Kesehatan Masyarakat. Jakarta: Pusdik SDM Kesehatan Kemenkes.

Putra, R. N. Y., Ermawati, Amir, A. 2016. Hubungan indeks massa tubuh (imt) dengan usia menarche pada siswi SMP Negeri 1 Padang. Jurnal Kesehatan Andalas, 5(3), 551-557. 
Putri, R. M., Kurnia P. 2017. Pemanfaatan MOCAF (Modified Cassava Flour) dengan sagu (Metroxylon sago Rottb) terhadap sifat elongasi dan daya terima mie basah. The 6th University Research Colloquium. Universitas Muhammadiyah Magelang

Sahil, J., M. H. I. Al Muhdar , F. Rohman , I. Syamsuri. 2016. Sistem pengelolaan dan upaya penanggulangan sampah di kelurahan dufa- dufa kota ternate. BIOeduKASI, 4(2), 478487.

\section{UCAPAN TERIMAKASIH}

Pelaksanaan kegiatan ini tidak lepas atas dukungan dan kerjasama berbagai pihak diantaranya Lembaga Penelitian dan pengabdian Masyarakat UAD, seluruh warga Dusun Klapaloro dan Temu Ireng serta seluruh mahasiswa KKN Reguler UAD Periode 65 Divisi XIC. 